\title{
Enikő Tóth \\ Some insights on demonstrative use in Hungarian: results of a controlled-dialogue game
}

\begin{abstract}
The aim of this paper is to collect and examine spontaneous data on Hungarian nominal demonstratives. Taking as a starting point Piwek et al.'s (2008) work on Dutch, conversations between two interlocutors were video recorded in a controlled-dialogue game setting. After a quantitative analysis of the distribution of pragmatic uses of Hungarian demonstratives, two hypotheses regarding the choice of exophoric proximal and distal demonstratives were tested, namely, it was explored whether relative distance from the speaker and mental accessibility influence demonstrative practice. The findings indicate that while relative proximity is a decisive factor, accessibility is not crucial. The paper also offers a detailed investigation of the various pragmatic uses of Hungarian demonstratives with the help of illustrative examples analysed in context.

Keywords: nominal demonstrative, Hungarian, distance, accessibility, pointing gesture
\end{abstract}

\section{Introduction}

\subsection{Deixis and demonstratives}

It is a basic fact about language use that during everyday communication people frequently refer to objects in their physical surroundings, thereby creating a direct link between language and the real world. Deixis, an intriguing linguistic phenomenon at the semantics/pragmatics interface, is concerned with the study of "linguistic expressions that are used to indicate elements of the situational and/or discourse context, including the speech participants and the time and location of the current speech event" (Diessel 2012: 2408). It is a very important feature of demonstratives that their meaning and use depends heavily on extra-linguistic, contextual clues. Tátrai (2017) emphasizes that deixis is a context-dependent, attentiondirecting linguistic operation that is rooted in the interlocutors' physical and socio-cultural world during the process of discourse interpretation. He argues in a functional cognitive framework that discourses develop as joint attentional scenes. These include the interaction of the interlocutors, who direct and follow the others' attention while construing a referential scene. The use of prototypical deictic expressions, for example that of demonstratives, provides context-dependent vantage points that help the addressee in processing and understanding the spatial, temporal and socio-cultural relations of the referential act via creating a deictic link between the joint attentional scene and the referential act. Hence, 
demonstratives cannot be interpreted without analysing the spatial, temporal and sociocultural context in which they have been uttered. Deixis is a pervasive feature of languages; demonstratives can be found across all languages and are widely used in everyday communication (Diessel 1999).

Hungarian has a two-term nominal demonstrative system; ez, ezek 'this, these' are traditionally described as proximals, while $a z$, azok 'that, those' are distals. Both of these terms can be used as pronominal or adnominal demonstratives, however, I will not differentiate these syntactic functions in the analysis. The aim of the study reported here is twofold: (i) to collect empirical data in the form of samples of spontaneous language use in order to explore the use of Hungarian exophoric demonstratives in a controlled elicitation task; and (ii) to investigate the role of two factors in the choice of Hungarian gestural demonstratives. The factors to be tested are the following:

- the traditional, but often debated factor of relative distance from the speaker;

- the cognitive factor of (mental) acceptability.

In addition, as other types of pragmatic use are also represented in the data, non-exophoric uses of Hungarian demonstratives will also be briefly discussed. Overall, the paper presents not only a corpus-based analysis of the pragmatic multi-functionality of Hungarian nominal demonstratives, but also investigates factors influencing demonstrative choice.

\subsection{Pragmatic uses of demonstratives}

Many accounts of demonstrative use adopt a taxonomic approach when describing the diverse functions fulfilled by demonstratives. Here I will present only those categories that are relevant for the purpose of this study.

Diessel (1999) differentiates exophoric and non-exophoric uses. According to Levinson $(1983,2004)$, the most basic use of demonstratives is the former one, when speakers orientate the addressee in the speech situation by drawing their attention to certain entities, hence, in order to be able to identify the referent of the demonstrative, the speech event has to be monitored physically, i.e. the referent can only be established based on the audio, visual and tactile features of the speech situation. Exophoric reference can be manifested in two different ways: the use of the demonstrative might either be accompanied by a gesture on the part of the speaker or not. The former uses are labelled as gestural, i.e. the act of referring, the deictic function is jointly performed by the deictic expression and the non-verbal gesture. For example, when uttering (1), the speaker is referring to an object in the speech situation and the utterance is probably accompanied by an extra-linguistic gesture (a pointing gesture, a head nod or eye gaze) on the part of the speaker.

\section{(1) Ezt kérem./ Ezt a könyvet kérem. (Laczkó 2008: 320, 321) \\ 'I want this./ I want this book.'}

According to Lyons (1977), this is the genuine case of deixis, hence, gestural uses may be treated as prototypical cases of deictic reference. As Tátrai (2017) notes, when the referent is not identified by means of a non-verbal gesture, but by relying on the shared knowledge of the spatial, temporal and socio-cultural parameters of the speech situation, then we talk about symbolic uses. Such uses always refer to some contextually available information shared by the interlocutors, but the referent is not necessarily part of their immediate physical environ- 
ment. For example, in the case of (2), it is clear for both the speaker and the addressee that the demonstrative phrase refers to the city where they are staying at the time of the utterance:

(2) A legjobb állatkert Magyarországon ebben a városban van.

'The best zoo in Hungary is in this city.'

Non-exophoric uses include anaphoric and discourse deictic uses among others. Anaphoric and discourse deictic expressions do not refer directly to the extra-linguistic context, instead, they refer to parts of the ongoing discourse. Anaphoric demonstratives co-refer with another noun phrase within the text, which means that they refer to an entity that another term, their antecedent picked out. Within anaphoric uses a further distinction is made between anaphora and cataphora depending on the position of the referring term. Anaphora is illustrated by (3), here the demonstrative co-refers with its antecedent, ${ }^{1}$ a noun phrase in the previous sentence. In the case of cataphora, the demonstrative co-refers with a postcedent phrase, as in (4):

(3) Ja hogy a Ponyvaregényről van szó. Ha nem lennék ilyen álmos, most azonnal megnézném azt a filmet, annyira szeretem. (Laczkó \& Tátrai 2012: 249)

'Oh, you are talking about Pulp Fiction. If I were not so sleepy, I would immediately watch that movie, I like it so much.'

(4) Ezt a filmet meg kellene nézned. A Blöff a legjobb film, amit valaha láttam.

'You should watch this movie. Snatch is the best film I have ever seen.'

Discourse deictic demonstratives "focus the hearer's attention on aspects of meaning, expressed by a clause, a sentence, a paragraph, or an entire story" (Diessel 1999: 101), or, in Levinson's words, they refer "to portions of the unfolding discourse" (Levinson 1983: 62). As an example, consider (5) below:

(5) A: Péter megbukott a vizsgán.

'Peter failed the exam.'

B: $E z$ nem igaz.

'That's false.'

After this brief survey of different types of demonstrative uses it is important to bear in mind that, as Levinson (2004: 107) claims, "the relations between these uses are probably more complex than this taxonomy suggests". For example, exophoric and anaphoric uses might overlap, as in the example below:

(6) I cut a finger: this one. (Levinson 1983: 67)

In (6) this one and a finger co-refer, however, the referent can only be identified by an accompanying gesture in the speech situation.

If we compare discourse deictic and anaphoric uses, the basic difference is that in the former case the demonstrative points to some element of the given discourse context, while in

1 Antecedents and postcedents will be marked by underlining throughout the paper. 
the latter it establishes a co-reference relation, and it is not the demonstrative itself that identifies the entity under discussion. However, as Laczkó (2010) notes, discourse deictic and anaphoric reference might also overlap. In (7) below, $e z$ fulfils a discourse deictic function, but the distal demonstrative $a z$ represents a borderline case between anaphora and discourse deixis (Laczkó 2010: 114):

(7) Péter tegnap vett egy új könyvet. Hazafelé ezt / azt olvasta a buszon.

'Peter bought a new book yesterday. On his way home, he was reading this / that on the bus.'

Nevertheless, it is clear that the wide range of functions performed by demonstratives both within and across languages provides a challenge for a proper treatment and analysis. In what follows I will explore the various uses of Hungarian demonstratives based on data that I collected in a production task. The structure of the paper is as follows. Section 2 describes the methodology used and presents the hypotheses tested. Section 3 elaborates on the findings, while Section 4 concludes the study.

\section{The controlled dialogue game}

\subsection{Methodology}

The work reported here is primarily aimed at exploring the use of exophoric demonstratives in Hungarian. ${ }^{2}$ Taking as a starting point Piwek et al.'s (2008) work on Dutch, I collected samples of spontaneous language use via a game in a controlled setting in order to elicitate as many instances of demonstrative occurrences as possible. More specifically, I video recorded conversations between two interlocutors working to reach a common goal in a so called controlled dialogue game while manipulating LEGO DUPLO blocks in table-top space (Piwek et al. 2008). The recordings were later transcribed.

The recorded conversations revolve around and concentrate on the here and now of the task to be performed. Naturally, participants often refer to the LEGO blocks, to the entities that have a crucial role in achieving their goal. Thus, due to the nature of the task, a relatively high number of demonstrative expressions were elicitated. A more detailed description of the game will be given in Section 2.3, but some examples taken from the corpus compiled from the task-oriented dialogues are given below. ${ }^{3}$ A gestural use of $a z$ 'that' can be seen in (8), while a discourse deictic use of $e z$ 'this' is illustrated by (9):

(8) Instruktor: És most szedd le róla azt a kis kockát $(\rightarrow)$.

Instructor: 'And now take down that little block $(\rightarrow)$.'

(video8)

(9) Instruktor: [hosszabb utasítást ad] Ezt így meg lehet csinálni?

Instructor: '[lengthy instruction] Can you do this?'

(video1)

2 It is important to note that the study reported here focuses on nominal demonstratives only.

3 “ $\rightarrow$ " indicates a pointing gesture throughout the paper. 
The method outlined above has both advantages and disadvantages. First of all, by this type of elicitation method it is possible to gather a relatively great number of occurrences of the target items quickly, especially as compared to traditional observational methods. Although the transcription itself is tedious and time-consuming, one can always watch the corresponding video segment, so contextual clues are not lost. A tremendous benefit of this method over the observation of naturally occurring speech is that the situational variables can be controlled. As a disadvantage, it has to be mentioned that at the beginning of the recording some participants felt self-conscious or were shy, which obviously might have affected their behaviour. Nevertheless, their way of acting became less guarded and more natural as they engaged in solving the task. Overall, the results of the study are limited to a certain extent, since the setting is artificial, and the findings cannot be generalized to demonstrative use per se, but the study is still built on data gained from natural communication.

\subsection{The hypotheses}

The analysis focuses on those occurrences of demonstratives that were accompanied by a manual pointing gesture on the part of the speaker. ${ }^{4}$ However, other uses of demonstratives will also be discussed to a certain extent. Following Piwek et al.'s (2008) work on Dutch, I examined two factors: relative distance and (mental) accessibility. Though the empirical setup was limited to table-top space, i.e. all LEGO blocks were located relatively close to the participants, it was still possible to explore whether relative proximity of the entities to the speaker has an effect on demonstrative choice. In this section I introduce the factors under investigation.

The role of relative distance in the choice of gestural demonstratives has been widely studied; however, the exact nature of the notion itself has usually been left unspecified. Kemmerer (1999) presents neuropsychological evidence in favour of the claim that near and far have different perceptual representations, and the brain applies different mechanisms when representing near vs. far space. The distinction stems from the fundamental human need to manipulate objects directly and the need to visually identify and analyse objects in the environment.

Kemmerer (1999) argues that demonstrative systems across languages do not in general encode space in the same manner, since demonstratives "specify abstract semantic notions that, when combined with the unique pragmatic features of communicative contexts, allow speakers to make a virtually unlimited range of spatial distance contrasts" (Kemmerer 1999: 35). Nevertheless, in order to operationalize the notion of relative distance in a closed setting, we will treat entities that are located physically within easy arm's reach, i.e. entities that can be touched without effort, as being close, while everything else will be considered to be far regarding the speaker's point of view. It has to be noted here that due to the nature of the task, since the participants interact in table-top space, most of the entities being referred to are within easy arm's reach of the speaker. ${ }^{5}$ The participants of the game were located next to each other, therefore their perspective was the same. Entities that occur within the area marked by the oval in Figure 1 were treated as being close to the speaker.

\footnotetext{
4 To widen the scope of study, gaze direction and head nods could be analysed. This is left for future research.

5 Demonstrative reference in elicitation tasks is discussed in a detailed fashion by Wilkins (1999).
} 
Some insights on demonstrative use in Hungarian: results of a controlled-dialogue game Argumentum 16 (2020), 209-229

Debreceni Egyetemi Kiadó

DOI: 10.34103/ARGUMENTUM/2020/13

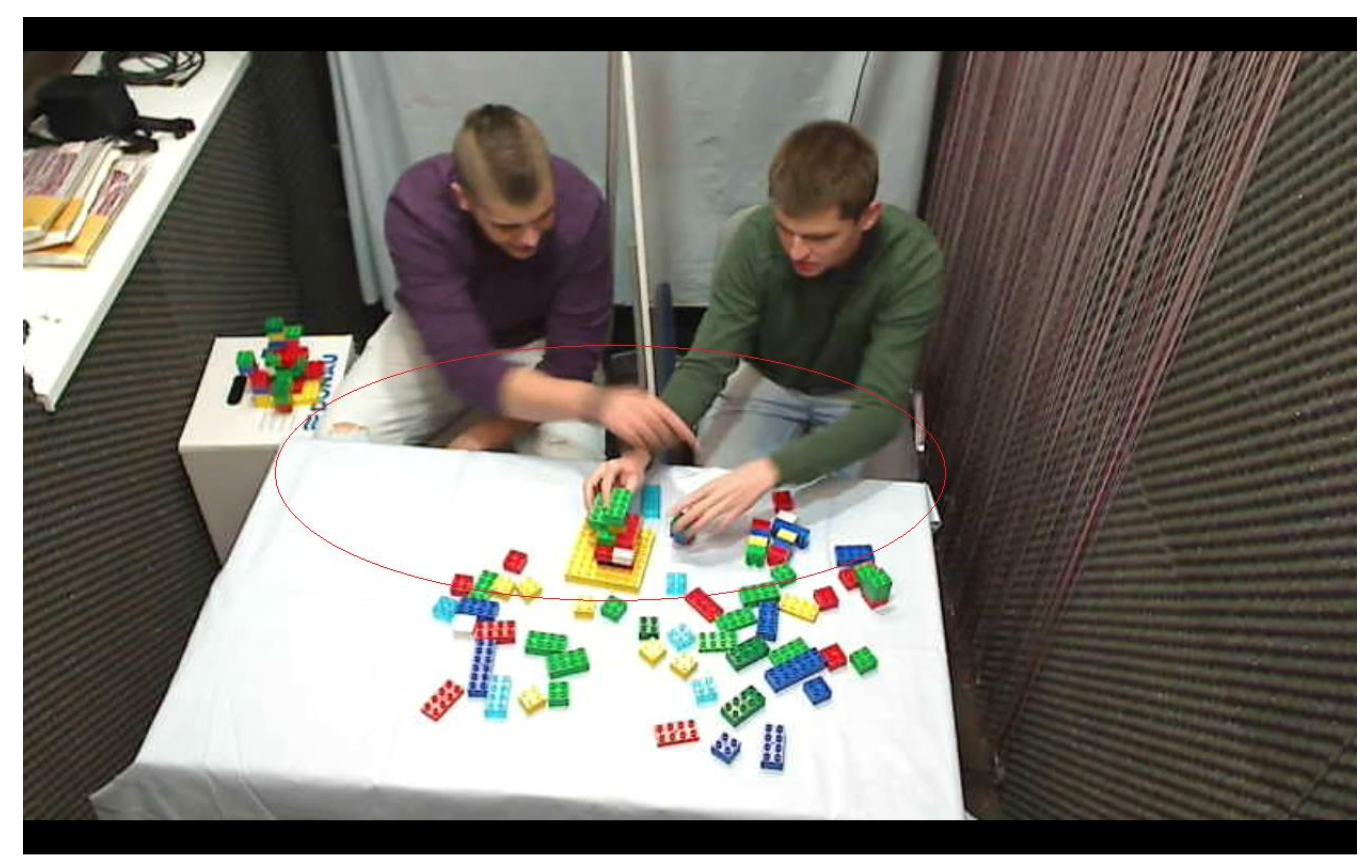

Figure 1. Entities located close to the interlocutors

The corresponding hypothesis regarding the choice of demonstratives is given below:

\section{Hypothesis 1}

Proximal demonstratives are selected to refer to entities that are within easy arm's reach of the speaker, while distal demonstratives are preferred to refer to entities that are further away in table-top space.

Turning to the second factor, accessibility and cognitive status have been analysed by a number of authors (see among others Ariel 1990/2014, 2004, Gundel et al. 1993, Strauss 2002). For instance, Ariel (2004) describes accessibility in terms of topicality, distance and competition. She notes that ,mental entities corresponding to discourse topics are highly accessible. So are representations of entities recently mentioned (short distance) and ones that have no competing candidates. Entities that are not topical, that were mentioned a while ago, and that have to compete with other candidates [...] are entertained at a lower degree of accessibility" (Ariel 2004: 99-100). In a similar fashion, Kahneman (2003: 699) identifies accessibility with "the ease [of mental effort] with which particular mental contents come to mind". Regarding the use of exophoric demonstratives, Strauss (2002) emphasizes the role of the speaker's presumed knowledge about the addressee's ability to identify the referent and the speaker's assessment regarding the relative importance of the intended referent. She argues that the use of this in spoken American English involves a tacitly expressed instruction to the addressee that they should pay more attention to the intended referent, usually because it conveys new information, while the use of that indicates that the information carried is more familiar and less important for the hearer as judged by the speaker, therefore the identification of the referent is easier. As Jarbou (2010) points out, these different definitions of accessibility are not necessarily incompatible, in fact they all describe a kind of verbal 
pointing, i.e. a common feature is that the speaker wants to draw the attention of the addressee to the intended referent.

Thus, relying on Strauss's (2002) and Ariel's (2004) work, accessibility as a working notion will be defined as follows:

- an entity is associated with low accessibility if, according to the speaker's assessment, the addressee is invited to consider it to be new, unexpected or important, i.e. an effort is required on the part of the addressee to identify the referent;

- an entity is associated with high accessibility if it is already known to the addressee, i.e. less effort is necessary on the part of the addressee to identify the referent.

Accordingly, the second hypothesis to be tested is given below (see also Piwek et al. 2008):

\section{Hypothesis 2}

Proximal demonstratives are selected by speakers to refer to entities that are associated with low accessibility, while distal demonstratives are selected to refer to entities associated with high accessibility.

The hypotheses described above were tested only against the data collected on the exophoric use of demonstratives.

\subsection{Design and participants}

Ten pairs of university students participated in the experiment, all native speakers of Hungarian, their average age was 20.5. The subjects were randomly selected, there were 11 male and 9 female participants. They were asked to engage in a so called controlled dialogue game (Piwek et al. 2008), where they worked with LEGO blocks of the DUPLO series in table-top space. Participants were asked to rebuild a construction, one of them acted as instructor, the other as builder. The two participants were separated by a screen, in that way only the instructor had visual access to an example building, and with his help the builder had to rebuild a construction that was visible to both (see Figure 2). Their common goal was to set up a building that is identical to the example. In order to avoid unnatural use of demonstratives, subjects were unaware of the aim of the study. The dialogue games were recorded on video and subsequently transcribed. 


\section{Enikö Tóth:}

Some insights on demonstrative use in Hungarian: results of a controlled-dialogue game Argumentum 16 (2020), 209-229

Debreceni Egyetemi Kiadó

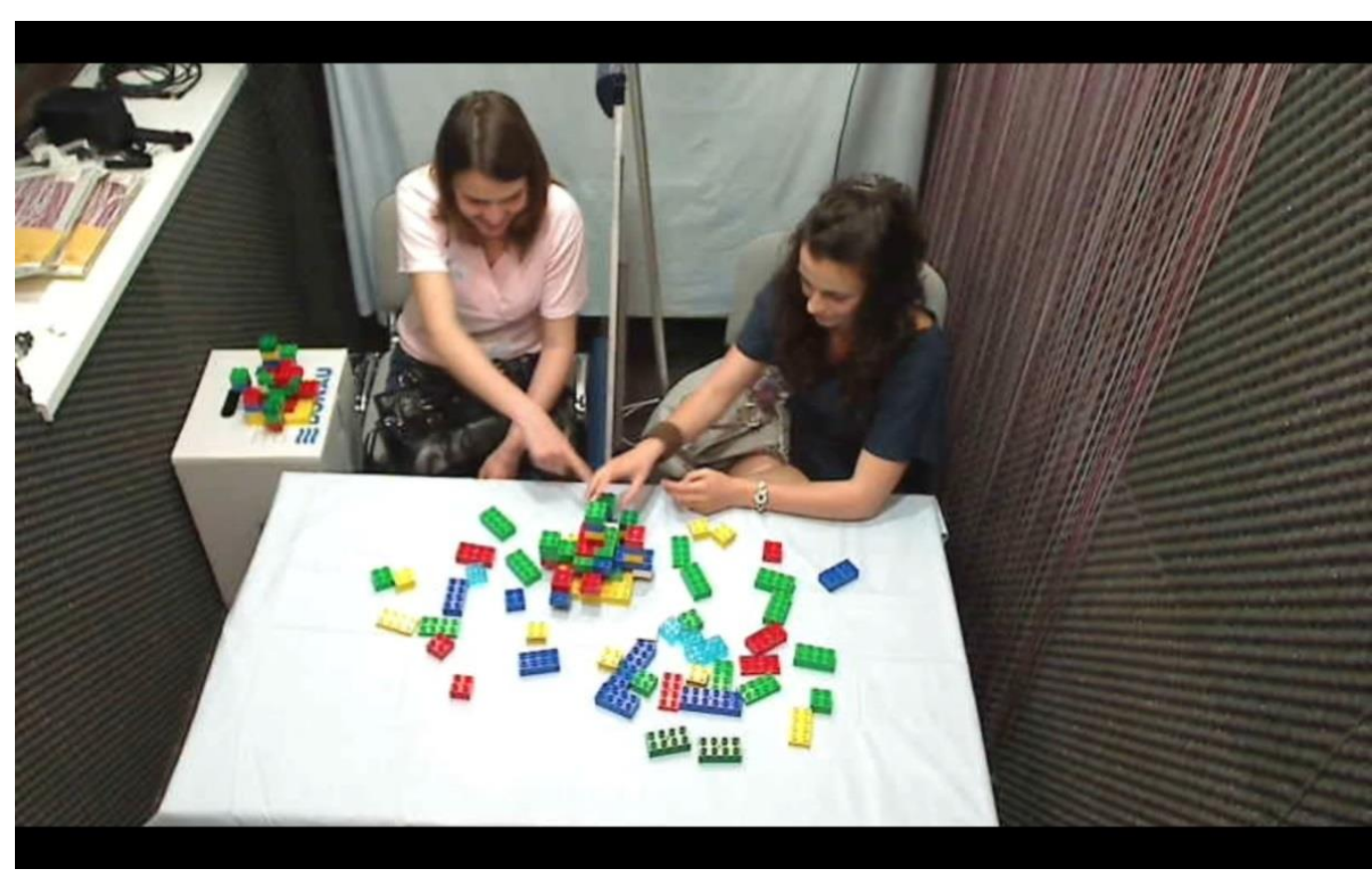

Figure 2. The layout of the game

\section{Results and discussion}

\subsection{Overall results}

Altogether there were 727 demonstrative expressions in the dialogues obtained; out of these 566 were exophoric and 161 were non-exophoric. ${ }^{6}$ Exophoric uses were further categorized into gestural (where the speaker is pointing at the intended referent ${ }^{7}$ ) and symbolic uses (there is no pointing gesture on the part of the speaker). Gestural uses also include cases where the speaker is holding the entity being referred to. The distribution of exophoric uses over proximal and distal demonstratives is shown in Table 1.

6 The categorization of exophoric vs. non-exophoric, more specifically, the distinction between exophoric and anaphoric demonstratives was not always straightforward, since the boundaries between the categories are somewhat blurred, as illustrated by example (6) in Section 1. I will discuss the criteria to tell these categories apart when I turn to the discussion of non-exophoric demonstratives.

7 Eye gaze and head nod were not analysed, only the presence of a pointing gesture on the part of the speaker was categorised as a case of gestural use. 
Enikö Tóth:

Some insights on demonstrative use in Hungarian: results of a controlled-dialogue game Argumentum 16 (2020), 209-229

Debreceni Egyetemi Kiadó

DOI: $10.34103 / A R G U M E N T U M / 2020 / 13$

\begin{tabular}{|c|c|c|c|c|}
\hline \multicolumn{5}{|c|}{ Exophoric uses } \\
\hline \multicolumn{2}{|c|}{ Gestural uses } & \multicolumn{2}{c|}{ Symbolic uses } \\
\hline \multicolumn{2}{|c|}{456} & proximal & distal \\
\hline \multicolumn{2}{|c|}{ proximal } & \multicolumn{2}{c|}{ distal } & 26 \\
\hline holding & not holding & holding & not holding & \\
\hline 115 & 235 & 7 & 99 & \\
\hline
\end{tabular}

Table 1. Distribution of exophoric demonstratives

I also distinguished different categories within non-exophoric uses. We will turn to these in Section 3.4.

\subsection{Gestural uses}

Table 2 displays the distribution of gestural uses. ${ }^{8}$ The results have been analysed by computing chi-square statistics. Regarding distance, there is a significant difference between entities located within easy arm's reach (near) and entities positioned further away from the speaker (far) and the choice of demonstratives (proximal vs. distal), hence the first hypothesis is kept. $\left(\chi^{2}(1)=112.865, p<0.001\right)$. The distribution of gestural demonstratives over distance is shown in Figure 3.

\begin{tabular}{|c|c|c|c|}
\hline \multicolumn{5}{|c|}{ Gestural uses } \\
\hline \multicolumn{3}{|c|}{456} \\
\hline proximal & far & near & fistal \\
\hline near & 350 & 45 & 61 \\
\hline 316 & 34 & HA & LA \\
\hline HA & LA & 46 & 60 \\
\hline 175 & 175 & & \\
\hline
\end{tabular}

Table 2. Distribution of gestural uses over the factors examined

8 HA stands for high accessibility, while LA stands for low accessibility. 
Enikö Tóth:

Some insights on demonstrative use in Hungarian: results of a controlled-dialogue game Argumentum 16 (2020), 209-229

Debreceni Egyetemi Kiadó

DOI: $10.34103 / A R G U M E N T U M / 2020 / 13$

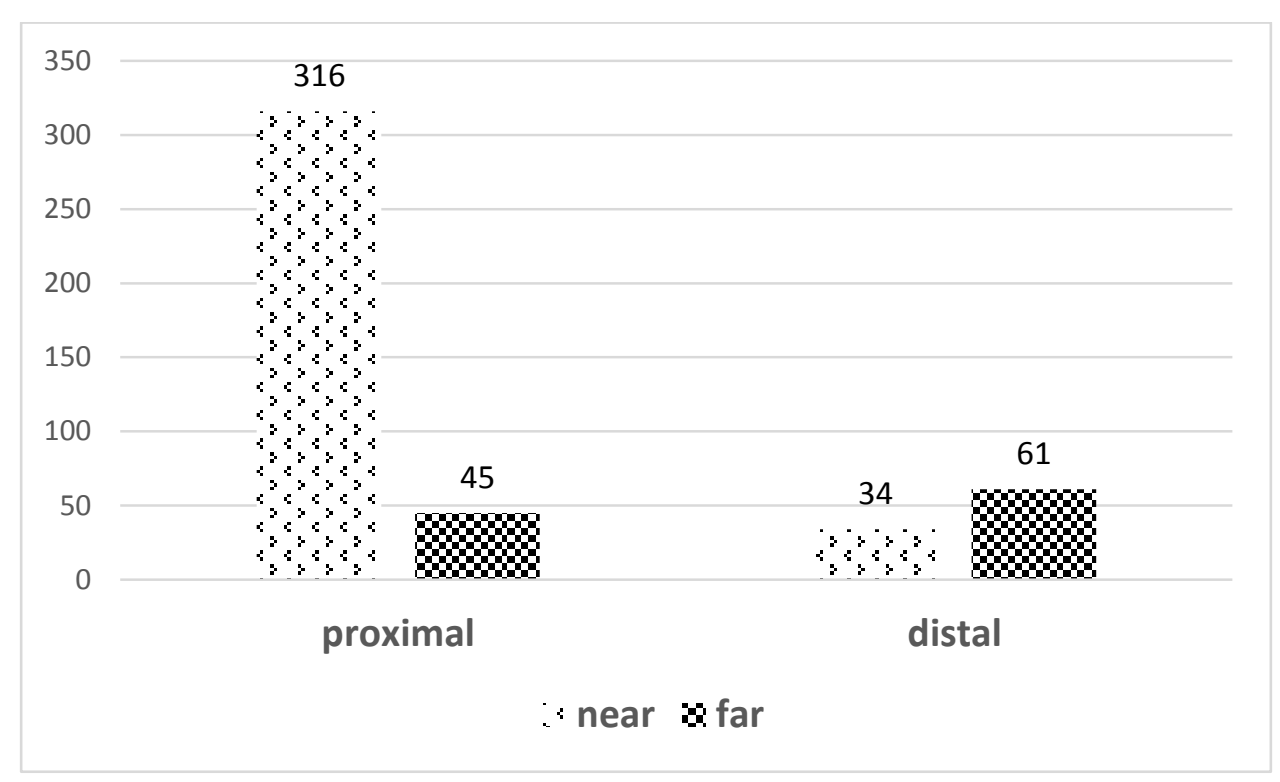

Figure 3. Distribution of gestural demonstratives over distance in Hungarian

Hence, distance matters, it influences the choice of Hungarian gestural demonstratives in table-top space: in general, proximals were used when referring to entities located within easy arm's reach of the speaker, while distals were preferred when referring to entities further away. Similar findings have been reported in a production experiment by Reile (2015) regarding the use of Estonian demonstrative adverbs.

As I have mentioned, due to the nature of the task, the majority of entities being referred to have been located within easy arm's reach of the participants, this explains the high distribution of proximals, they constitute 76.7 per cent of gestural uses. ${ }^{9}$ Typically, when the builder was talking about a given part of the structure, or manipulating a block of LEGO, he used the proximal term. In fact, there are many cases when the builder is holding the entity in question, 33 per cent of proximal gestural demonstratives refer to an entity that is being held by the speaker (see Table 1). Kibrik (2011: 510) differentiates five subtypes of pointing, as follows:

- out-of-arm-reach, distal pointing;

- within-arm-reach, proximal pointing;

- reaching;

- touching;

- holding, handling.

Kibrik (2011) describes this as a scale of continuum, where the borders between the categories are fluid, but argues that each of these gestures directs the attention of the addressee. The important point is that holding something is a special type of pointing, and since the entities in question are obviously close to the speaker, the use of the proximal form is expected. The other types of pointing from the scale above have all been exemplified in the recorded dialogues.

\footnotetext{
As pointed out by the anonymous reviewer of this paper, a possible explanation for the high proportion of proximals is that speakers might ignore distance in this close space, but still consider the location of objects relative to one another, and the objects being manipulated are definitely closer to them with respect to others.
} 
The use of distals to refer to entities out of arm's reach in this limited space is not unexpected, either. For example, Wilkins (2018) states that Arrernte speakers used distal demonstratives in an elicitation task when referring to the furthest object located on the away axis across a table within 0.7 meter.

Turning to the role of accessibility, there is no significant difference between high or low accessibility and the choice of demonstratives (proximal vs. distal), thus, the second hypothesis is rejected $\left(\chi^{2}(1)=1.421, \mathrm{p}=0.233\right)$; the choice of proximals versus distals is not dependent upon the accessibility of the referent in Hungarian. As it is evident from Table 2, speakers used exactly the same number of proximal demonstratives to refer to highly and lowly accessible entities, and distals exhibit a very similar pattern. Results concerning accessibility are controversial in the relevant literature. For example, Piwek et al. (2008) accepts the same hypothesis for Dutch in a similar controlled dialogue game setting, concluding that there is a correlation between low accessibility and gestural proximals, and high accessibility and distals. According to Jarbou (2010), just the opposite can be observed in spoken Jordanian Arabic. Many authors note that the notion of accessibility is not welldefined (cf. Burenhult 2003, Hanks 2009). Hence, further studies may be required that are based on a more exact notion of accessibility, at least in an empirical framework.

As in interim summary we can conclude that while relative distance from the speaker is a crucial factor, the choice of proximals versus distals is not dependent upon the accessibility of the referent in Hungarian. The results obtained from the data gathered in the controlled dialogue game have to be handled with caution, since all referents were located relatively close both to the instructor and to the builder in table-top space. Nevertheless, both proximal and distal demonstratives were used, and it is also clear from Figure 3 that speakers also used proximal demonstratives to refer to entities being far from the speaker, while distals were used to refer to entities that were within arm's reach, too. Some representative cases will be discussed in the next section. Obviously, such examples challenge the traditional view of demonstrative choice and give rise to the assumption that other factors can play a role besides (or instead of) relative distance from the speaker; or there might be an interaction of several factors that determines demonstrative use. Though accessibility as a factor has been discarded above, its role needs to be reconsidered, since it might interact with other factors. This assumption is also motivated by Peeters et al.'s (2014) claim that in Piwek et al.'s (2008) study on Dutch physical proximity and accessibility (i.e. the notion of focus of attention) must have interacted.

\subsection{The role of distance - some examples}

In what follows I will take a closer look at examples where the traditional near/far opposition cannot adequately explain the use of demonstratives in Hungarian. In each case I will examine the various contextual factors that might play a role.

First, let us consider an example where a proximal term is used to refer to an entity that is far from both participants:

(10) Instruktor: Utána jön egy ugyanakkora kék, utána pedig ez a zöldes kékes $(\rightarrow)$. Instructor: 'Then comes a blue one, same size, then this bluish-greenish one $(\rightarrow)$.' (video6) 
The instructor is referring to a block that is located among the spare blocks they can use, out of arm's reach. However, the one he is pointing at is closer to him and to the addressee than the other block of the same kind. Thus, there are two blocks of the same kind, they have the same characteristic features in terms of size, shape, colour, etc., both are located relatively far (out of arm's reach) from the speaker and the addressee, and the speaker is pointing at the one that is closer to him. In doing so, he evokes a contrast between the two blocks, and by relativizing distance he successfully guides the attention of the addressee to the intended referent, namely, the addressee can identify the referent. As Kemmerer argues "demonstratives do not encode metrically precise degrees of remoteness from the deictic centre, but rather have abstract meanings that are pragmatically modulated by either the discourse context or the referential scenario, thereby allowing speakers to flexibly expand or contract the concentric zones so as to express a potentially unlimited range of distance contrasts" (Kemmerer, 2006: 1608). From another perspective it can also be assumed that the instructor wants to direct the attention of the builder to an entity that is important in Strauss's (2002) terms, consequently, accessibility might overwrite distance.

The next example shows that a distal demonstrative might be used to refer to an entity that is close to the interlocutors. In the example below, the instructor is referring to a given part of the construction that is within arm's reach of the participants:

(11) Instruktor: Megfordítod egy picit, hogy $a z(\rightarrow)$ felém legyen.

Instructor: 'Will you turn it a little, turn that $(\rightarrow)$ toward me.'

(video5)

In (11), the speaker refers to a given side of the construction. At the time of speaking, this side is further away than the one that is facing him, and obviously, there is an inherent contrast in between the two sides. It has been shown for example by Tóth et al. (2014) that in contrastive contexts the distal demonstrative can be used to refer to an entity that is close to the speaker. Thus, the contrast evoked here, i.e. that the builder would like to look at that side of the building, not this one, might trigger the use of the distal demonstrative. As an alternative explanation, it could also be argued that the intended referent, the other side, is not visible at the time of speaking. Perceptibility or visibility has been considered as potential factors by Jarbou (2010) and Coventry et al. (2008).

Similarly, the block being referred to is located at the far side of the construction, but still within arm's reach of the speaker in (12). In addition, since the speaker cannot adequately describe the object and uses a whatdoyoucallit expression to refer to it, it might be argued that there is a kind of mental distance between the speaker and the entity. ${ }^{10}$

(12) Intruktor: Elcsúszott az az izé $(\rightarrow)$.

Instructor: 'That whatever it is $(\rightarrow)$ has slipped away.'

(video1)

The speaker can also create a contrast explicitly, when referring to entities that are located at the same distance, but in order to distinguish them and to refer to them one by one, the

\footnotetext{
10 I thank the anonymous reviewer for this suggestion.
} 
speaker opts for a proximal and a distal term, respectively. In the following example the entities being referred to are within arm's reach of the participants.

(13) Instruktor: Úgy kéne állnia, hogy ez $(\rightarrow)$ így összeérjen azzal $(\rightarrow)$.

Instructor: 'It should be positioned in a way that this $(\rightarrow)$ adjoins that $(\rightarrow)$.'

(video1)

A remarkable type of demonstrative use is when the speaker is holding the entity being referred to, but selects a distal demonstrative. The examples in question are peculiar, because they sometimes represent borderline cases between spatial reference and anaphora, as in (14). However, if we consider holding as a subtype of pointing, then the cases in question are to be labelled as exophoric uses. There were seven such examples in the recorded conversations. Having a closer look at these discourse segments reveals that in each case the speaker is the builder, and he is repeating an instruction issued by the instructor. In six of the examples this is almost a word by word repetition, and in the remaining one it is a reflection on the instruction, where the builder makes sure that he has managed to find the right block. Two relevant examples are given below:

(14) Instruktor: És azt $(\rightarrow)$ tedd át.

Instructor: 'And put that one $(\rightarrow)$ there.'

Építő: $\quad$ És azt (fogja) tegyem át.

Bulider: 'And I will put that one (holding) there.'

(video4)

(15) Instruktor: Alul a kéket, tehát alul

Instructor: 'The blue one below, I say, below'

Építő: $\quad \mathrm{Ja}$, azt az alsó kéket (fogja) cserélem ki egy kicsi pirosra.

Builder: 'Ah, I exchange that blue one below (holding) for a small red one.'

(video5)

In the following fragment the builder again wants to check whether he has understood which entity was meant by the instructor, but this is achieved by using the proximal demonstrative. The object in question is at the same distance from the interlocutors, but the builder is holding it. This is crucial, since Coventry et al. (2008) argue that it matters who is performing the action, namely they found that English speakers used this more often when they themselves were manipulating a given object in an experimental setting.

(16) Építő: Mennyire szedjem le?

Builder: 'How far do I have to remove it?'

Instruktor: Hát, csak azt a tetejét.

Instructor: 'Well, only that roof of it.'

Építő: $\quad E z t$ ? (fogja)

Builder: 'This one? (holding it)'

(video5) 
Interestingly, there are also cases where the speaker himself uses both demonstratives within the same utterance to refer to the same object. It is obvious that distance as a factor cannot explain this phenomenon. When analysing the examples below it is important to know what the speaker is doing at the time of speaking. In that way the selection of demonstratives can be analysed as a dynamic process. As a starting point, let us consider the example below:

(17) Instruktor: Vedd le a pirosat, mert az itt volt.

Instructor: 'Take down the red one, because that one was here.'

Építő: $\quad$ Melyik pirosat, ezt $(\rightarrow)$ ?

Builder: 'Which red one do you mean, this one $(\rightarrow)$ ?

Instruktor: Nem, azt $(\rightarrow)$ ott, ezt $(\rightarrow)$.

Instructor: 'No, not that one $(\rightarrow)$ there, this one $(\rightarrow)$.'

Építő: $\quad$ Ezt a pirosat $(\rightarrow)$ ? De alatta van.

Builder: 'This red one $(\rightarrow)$ ? But it is below another one.'

(video8)

It is important to point out that this is not a contrastive example; intonation and the use of gestures make it clear that the speaker is referring to the same block of LEGO. Jarbou (2010), who observed the use of demonstratives in Jordanian Arabic in spontaneous interactions, argues that in such cases either the perspective of the speaker has changed, or the hearer's attitude towards the referent has been modified. In the example above, the former explanation seems to be more plausible, since the speaker leaned closer to the object in question while producing the utterance. The last utterance by the builder confirms that she managed to identify the intended referent.

The next example illustrates the second option; when according to the speaker's assessment the hearer's attitude toward the referent changes. In (18) below, the speaker, the instructor, tries to clarify which block he is referring to. The demonstrative choice by the speaker reflects how he perceives the addressee's ability to recognize the intended referent: the use of the proximal term might indicate in accordance with the accessibility hypothesis that the speaker considers the referent to be lowly accessible, thus considerable effort is required on the part of the addressee. For that reason, the speaker is trying to guide the addressee in the process of finding the referent, and while doing that he adopts the hearer's perspective. This is the reason why he switches from the proximal form to the distal one when he adds further information about the intended referent accompanied by a pointing gesture:

(18) Instruktor: Ezt a pirosat $(\rightarrow)$ onnan vedd le, azt a kis picit $(\rightarrow)$ csak.

Instructor: 'Take this red one $(\rightarrow)$ from there, only that little one $(\rightarrow)$.' (video6)

\subsection{The role of pointing}

The discussion so far has been restricted to gestural demonstratives. However, when focussing on exophoric uses in general, a remarkable relationship between proximals and pointing gestures might be worth mentioning. Carrying out the same quantitative test for the relevant data, we find that proximals are often used with an accompanying pointing gesture, while distals occur almost as often with or without a pointing gesture $\left(\chi^{2}(1)=112.129, p<0.001\right)$, 
as shown in Figure 4. The distribution of proximals over gestural and symbolic uses is $93 \%$ vs. $7 \%$, while that of distals is $56 \%$ vs. $44 \%$. Tóth (2018) found the same pattern in a different experimental setting, i.e. participants selected proximal demonstratives significantly more often in the presence of a manual pointing gesture than distals. Hence, the present results reinforce the relation between the use of proximals and pointing gestures.

It can also be observed in Figure 4 that symbolic uses were more often realized with distal forms, in fact, there were three times as many distal demonstratives as proximals. A similar link has been found by Piwek et al.'s (2008) study of Dutch nominal demonstratives.

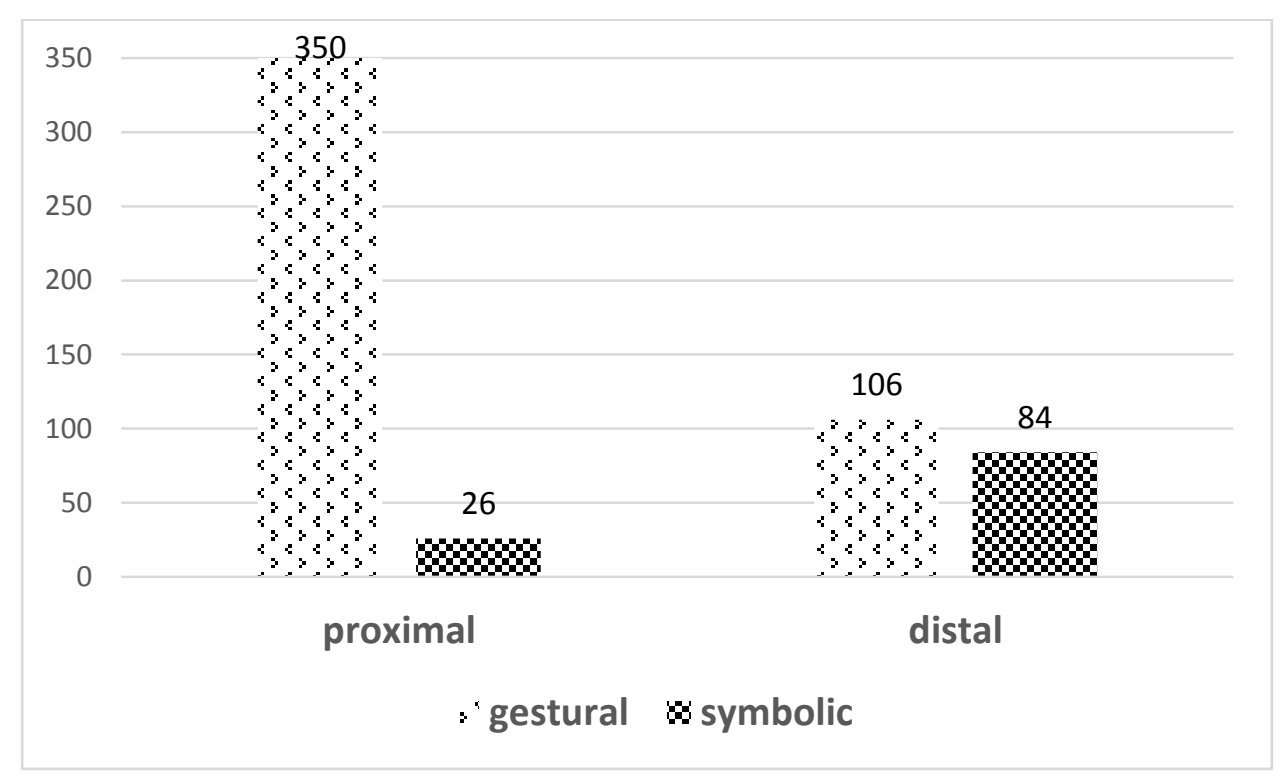

Figure 4. Distribution of demonstratives over exophoric uses in Hungarian

\subsection{Non-exophoric uses}

Let us now turn to a more detailed analysis of non-exophoric uses. Though these do not form the primary focus of this work, it is worth studying these examples as well. The frequency of the different subtypes is shown in Table 3. Discourse deictic and anaphoric uses have been introduced in Section 1.2, the category of resumptive pronouns will be described below. ${ }^{11}$

\begin{tabular}{|c|c|c|c|c|c|c|c|}
\hline \multicolumn{9}{|c|}{ Non-exophoric uses } \\
\hline \multicolumn{2}{|c|}{ Discourse deictic uses } & \multicolumn{2}{c|}{ Anaphoric uses } & \multicolumn{2}{c|}{ Resumptive } & \multicolumn{2}{c|}{ Other } \\
\hline \multicolumn{2}{|c|}{47} & \multicolumn{2}{c|}{71} & \multicolumn{2}{c|}{20} & \multicolumn{2}{c|}{23} \\
\hline proximal & distal & proximal & distal & proximal & distal & proximal & distal \\
\hline 35 & 12 & 1 & 19 & 2 & 18 & 3 & 20 \\
\hline
\end{tabular}

Table 3. Distribution of Hungarian non-exophoric demonstratives

11 The label 'other' includes demonstratives serving as clause associates of subordinate clauses (Szücs 2015) or as heads of nominal relative clauses (Kenesei 1994). Such cases will not be discussed here. 
Discourse deictic cases identified in the corpus usually refer to an utterance describing an instruction or an action. For instance, in (19), the distal demonstrative refers to an action described in the previous utterance:

(19) Építő: Megnézheted közelebbről is.

Builder: 'You can have a closer look.'

Instruktor: Jó, azt akarom.

Istructor: 'OK, that's what I want.'

(video5)

As mentioned before, it has been pointed out by various authors that there is a fuzzy boundary in between exophoric and non-exophoric uses of demonstratives, especially in the case of exophoric and anaphoric reference (see Lyons 1977, Levinson 2004, Laczkó 2008, 2010). When I categorized the individual occurrences of demonstratives, those cases were labelled as anaphoric where the demonstrative has an antecedent, and the anaphora serves to maintain an established attention on the referent. Hence, the occurrences of $a z$ in (20) and (21) are treated as anaphoric, since the referent of the pronoun is identified via the linguistic context.

(20) Instruktor: Vedd le a pirosat, mert $a z$ itt volt.

Instructor: 'Take down the red one, because that was here.'

(video8)

(21) Instruktor: Alulról, a legalsó fehéret.

Instructor: 'From below, the lowest white one.'

Építö: $\quad A z t$ vegyem le?

Builder: 'Shall I take that?'

(video5)

As opposed to that, exophoric reference, especially when there is a pointing gesture on the part of the speaker, is aimed at directing the attention of the addressee to the intended referent. In the example below, gestural reference serves as the antecedent of the distal demonstrative, hence spatial deictic reference overlaps with anaphoric reference:

(22) Építő: $\quad$ És ez az oldal $(\rightarrow)$, a másik oldallal szemben?

Builder: 'And this side, opposite the other one?'

Instruktor: Megnézem azt is, stimmel.

Instructor: 'I'll have a look at that, it seems right.'

(video2)

In (23), one anaphor is followed by another one, i.e. the antecedent of the first anaphor arra 'onto that' is the phrase egy piros-at 'a red block.ACC', and then three similar anaphors follow in an elliptical construction: 
(23) Instruktor: Ezt a zöldet $(\rightarrow)$ innen a sarokról vedd le és tegyél helyette egy pirosat.

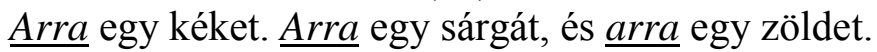

Instructor: 'Take this green one from the corner here and replace it with a red one. Put a blue block on $i t$, then a yellow and finally a green.'

(video2)

In the fragment below we find another non-exophoric use, the utterance by the builder contains a topic-repeating resumptive pronoun. Szalamin (1988) describes topic-repeating structures involving demonstrative pronouns as follows: "a clause-initial topic, a verbal argument, is followed by a typically unstressed resumptive pronoun without a pause; the pronoun agrees with the verbal argument in number and case and emphasizes the argument itself" (Szalamin 1988:91-92). ${ }^{12}$ In the generative tradition, Szücs (2019: 294) describes Hungarian left dislocation as a construction "whereby some discourse-prominent entity is placed at the left periphery of the clause, with a subsequent co-referential pronoun".

(24) Instruktor: Utána van egy sötétkék.

Instructor: 'Behind that one there is a dark blue one.'

Építő: Igen, a sötétkék $a z$ itt van.

Builder: 'Right, the dark blue that is here.'

(video4)

In fact, altogether there were 20 occurrences of resumptive pronouns in the corpus. As the example below shows, resumptive pronouns share number and case features with their antecedent.

(25) Instruktor: Meg a zöld-et $a z-t$ tedd vissza.

Instructor: 'And the green one.ACC, put that.ACC back.'

(video8)

Especially interesting are those two examples from the corpus where the resumptive pronoun is proximal. According to Szalamin (1988), the proximal demonstrative can function as a topic-repeating, resumptive pronoun when the topic itself is a demonstrative NP with a proximal adnominal in it:

(26) Instruktor: Ez a kiálló $e z$ alul piros.

Instructor: 'This jutted part this is red below.'

(video1)

(27) Instruktor: Ezt a részt $(\rightarrow)$ ezt itt bontsd le.

Instructor: 'This part $(\rightarrow)$ take this here apart.'

(video6)

12 “A mondat elején topik szerepet betöltő mondatrész, igei bővítmény áll, amelyet (vele egyeztetett alakban) kiemelő szerepü mutató névmás követ, többnyire hangsúly és beszédszünet nélkül.” 


\subsection{Individual variation}

Ten pairs participated in the experiment, and they followed quite different strategies while carrying out the task in the controlled dialogue game. As a result, some of them completed the task very quickly, but there were some lengthy conversations, too. The number of demonstratives used in the individual conversations and the duration of the dialogues are shown in Table 4.

\begin{tabular}{|c|c|c|c|c|c|c|}
\hline \multirow{2}{*}{ Number } & \multirow{2}{*}{ Participants } & \multirow{2}{*}{ Duration } & \multicolumn{3}{|c|}{ Number of demonstratives used } & \multirow{2}{*}{ Total } \\
\cline { 4 - 6 } & & & gestural & symbolic & non-exophoric & \\
\hline 1 & 2 women & $14: 10$ & 53 & 15 & 31 & 99 \\
\hline 2 & 2 men & $9: 10$ & 24 & 5 & 20 & 49 \\
\hline 3 & 2 men & $10: 50$ & 54 & 8 & 16 & 78 \\
\hline 4 & 1 woman/1 man & $14: 16$ & 35 & 19 & 25 & 79 \\
\hline 5 & 2 women & $15: 45$ & 36 & 16 & 19 & 71 \\
\hline 6 & 2 men & $19: 00$ & 98 & 15 & 20 & 133 \\
\hline 7 & 2 men & $5: 20$ & 0 & 1 & 3 & 4 \\
\hline 8 & 2 women & $20: 50$ & 117 & 9 & 11 & 137 \\
\hline 9 & 2 women & $7: 32$ & 27 & 8 & 9 & 44 \\
\hline 10 & 2 men & $6: 23$ & 12 & 14 & 7 & 33 \\
\hline Total & & & 456 & 110 & 161 & 727 \\
\hline
\end{tabular}

Table 4. List of the video recordings

In general, the majority of pairs, as expected, used a large number of nominal demonstratives, due to the nature of the assignment. However, there was one exception to this general tendency: a pair of two men (video7) worked very efficiently; they completed the task in the least amount of time, and, surprisingly, did not use gestural demonstratives at all. Taking a closer look at the conversation in question, it is revealed that the instructor used quite a lot of definite descriptions, and the builder often pointed at the block that he managed to identify based on the information carried by the description, but, contrary to expectations, he did not use a demonstrative to make sure that he picked the right one, as others often did.

Regarding the choice between a demonstrative and a definite description, it can be assumed that the use of gestural demonstratives helps to direct the attention of the addressee to the referent in a direct manner, in other words gestural demonstratives signal that the referent is easily identifiable out of the set of potential candidates. As opposed to that, processing a definite description might require more effort on the part of the addressee. Nevertheless, the participants in video 7 followed the seemingly more complex strategy, and it worked very efficiently.

Table 4 also shows that speakers usually produced more gestural demonstratives than symbolic ones in general, which is not surprising considering the specific demands of the task. This difference is especially remarkable in the case of pair 8 (two women), who produced the highest number of gesturals, 117, while only 9 symbolic demonstratives were used. The high number of demonstratives is matched by the length of the dialogue, and similar proportions obtain in the second longest dialogue, 98 and 15, respectively, produced 
by pair 6 (two men). However, in the latter case there was a misunderstanding regarding the instructions, members of this pair decided to remove all parts of the construction and then had to restart the task when they were warned that it is not allowed to that.

Turning to the use of non-exophoric pronouns we find another interesting difference among the pairs. Namely, some of them did not use topic-repeating pronouns at all, there were three such pairs altogether. As opposed to that, most pairs produced one or two such pronouns, while the highest number, six, was produced by two women (pair 1). Though the data collected here is not enough to draw any conclusions, in terms of individual variation the data might imply that there are speakers who do not use resumptive pronouns.

\section{Conclusion}

The study presented here explored the use of nominal demonstratives in Hungarian using data gained from natural conversations that were video recorded in a controlled dialogue game setting where two interlocutors worked to reach a common goal. A detailed analysis of nominal demonstrative occurrences revealed that the choice between proximal and distal gestural demonstratives in Hungarian is influenced by relative distance from the speaker, i.e. proximals were used when referring to entities located within easy arm's reach of the speaker, while distals were preferred when referring to entities further away. As opposed to that, accessibility, which was defined in terms of the processing effort required on the part of the addressee in identifying the intended referent, was not a decisive factor.

It was also shown that relative distance on its own cannot always explain the selection of exophoric demonstratives. Hence, the use of demonstratives can only be described as a dynamic process affected by the interaction of separate factors. These factors include perceptibility, visibility, pointing, manipulation and change of perspective or attitude. The results obtained in this preliminary study show that further studies based on different methodologies are called for in order to understand the subtleties of Hungarian demonstrative practice. Finally, non-exophoric uses of demonstratives were also briefly discussed in order to provide a more complete picture of Hungarian demonstrative use.

\section{References}

Ariel, M. (1990/2014): Accessing Noun-Phrase Antecedents. London, New York: Routledge. Reprinted: Ariel, Mira 2014. Accessing Noun-Phrase Antecedents (Routledge Library Editions: Linguistics). London, New York: Routledge. https://doi.org/10.4324/9781315857473

Ariel, M. (2004): Accessibility Marking: Discourse Functions, Discourse Profiles, and Processing Cues. Discourse Processes 37(2), 91-116. https://doi.org/10.1207/s15326950dp3702_2

Burenhult, N. (2003): Attention, accessibility, and the addressee: the case of the Jahai demonstrative ton. Pragmatics 13(3/4): 363-379. https://doi.org/10.1075/prag.13.3.01bur

Coventry, K. R., Valdés, B., Castillo, A. \& Guijarro-Fuentes, P. (2008): Language within your Reach: Near-far Perceptual Space and Spatial Demonstratives. Cognition 108, 889895. https://doi.org/10.1016/j.cognition.2008.06.010

Diessel, H. (1999): Demonstratives. Form, Function and Grammaticalization. Amsterdam: John Benjamins. https://doi.org/10.1075/tsl.42 
Diessel, H. (2012): Deixis and demonstratives. In: Maienborn, C., von Heusinger, K, \& Portner, P. (eds.): An International Handbook of Natural Language Meaning. Vol. 3. Berlin: Mouton de Gruyter, 2407-2431.

Gundel, J. K., Hedberg, N. \& Zacharski, R. (1993): Cognitive Status and the Form of Referring Expressions in Discourse. Language 69(2), 274-307.

Hanks, W. F. (2009): Fieldwork on Deixis. Journal of Pragmatics 41, 10-24.

Jarbou, S. O. (2010): Accessibility vs. physical proximity: an analysis of deictic demonstrative practice in spoken Jordanian Arabic. Journal of Pragmatics 42, 3078-3097.

Kahneman, D. (2003): A Perspective on Judgement and Choice: Mapping Bounded Rationality. American Psychologist 58(9), 697-720. https://doi.org/10.1037/0003066X.58.9.697

Kenesei, I. (1994): Subordinate clauses. In: Kiefer, F. \& É. Kiss, K. (eds.): Syntax and Semantics. Volume 27. The Syntactic Structure of Hungarian. San Diego \& New York: Academic Press, 275-354.

Kemmerer, D. (1999): Near and far in language and perception. Cognition 73, 35-63. https://psycnet.apa.org/doi/10.1016/S0010-0277(99)00040-2

Kemmerer, S. (2006): The semantics of space: Integrating linguistic typology and cognitive neuroscience. Neuropsychologia 44, 1607-1621. https://doi.org/10.1016/j.neuropsychologia.2006.01.025

Kibrik, A. A. (2011): Reference in Discourse. Oxford: Oxford University Press.

Laczkó, K. (2008): A mutató névmási deixisről. Általános Nyelvészeti Tanulmányok 22, 30947.

Laczkó, K. (2010): Demonstrative pronouns in spatial deixis, discourse deixis, and anaphora. Acta Linguistica Hungarica 57(1), 99-118. https://doi.org/10.1556/ALing.57.2010.1.5

Laczkó, K. \& Tátrai, Sz. (2012): "Személyek és/vagy dolgok. A harmadik személyü és a mutate névmási deixis a magyarban.” In: Tolcsvai Nagy, G. \& Tátrai, Sz. (eds.): Konstrukció és jelentés. Tanulmányok a magyar nyelv funkcionális kognitív leírására. Budapest: ELTE, 231-258.

Levinson, S. C. (1983): Pragmatics. Cambridge: Cambridge University Press. https://doi.org/10.1017/CBO9780511813313

Levinson, S. C. (2004): Deixis and Pragmatics. In: Horn, L. \& Ward, G. (eds.): The Handbook of Pragmatics. Oxford: Blackwell, 97-121.

Lyons, J. (1977): Semantics. Vol. 2. Cambridge: Cambridge University Press. https://doi.org/10.1017/CBO9780511620614

Peeters, D., Azar, Z. \& Özyürek, A. (2014): The interplay between joint attention, physical proximity, and pointing gesture in demonstrative choice. In: Bello, P., Guarini, M., McShane, M. \& Scassellati, B. (eds.): Proceedings of the 36th Annual Meeting of the Cognitive Science Society. Cognitive Science Meets Artificial Intelligence: Human and Artificial Agents in Interactive Contexts. Austin, TX: Cognitive Science Society, 11441149.

Piwek, P., Beun, R. \& Cremers, A. (2008): 'Proximal' and 'distal' in Language and Cognition: Evidence from Deictic Demonstratives in Dutch. Journal of Pragmatics 40, 694-718. https://doi.org/10.1016/i.pragma.2007.05.001

Reile, M. (2015): Space and demonstratives: An experiment with Estonian exophoric demonstratives. Eesti ja Soome-Ugri Keeleteaduse Ajakiri 6(2), 137-165. https://doi.org/10.12697/jeful.2015.6.2.06 
Strauss, S. (2002): This, that, and it in Spoken American English: a Demonstrative System of Gradient Focus. Language Sciences 24, 131-152. https://doi.org/10.1016/S0388$\underline{0001(01) 00012-2}$

Szalamin, E. (1988): Az ún. témaismétlő névmások kérdéséhez. In: Kontra, M. (ed.): Beszélt nyelvi tanulmányok. Budapest: MTA Nyelvtudományi Intézet, 90-101.

Szücs, P. (2015): On pronouns in Hungarian complex sentences. Argumentum 11, 292-313.

Szücs, P. (2019): Left Dislocation in Hungarian. In: Butt, M., King, T. H., \& Toivonen, I. (eds.): Proceedings of the LFG'19 Conference, Australian National University. Stanford, CA: CSLI Publications, 293-313.

https://web.stanford.edu/group/cslipublications/cslipublications/LFG/LFG-2019/lfg2019szucs.pdf (Accessed 26 March 2020).

Tátrai, Sz. (2017): Pragmatika. In Tolcsvai Nagy, G. (ed.): Nyelvtan. A magyar nyelv kézikönyvtára 4. Budapest: Osiris Kiadó, 899-1058.

Tóth, E., Csatár, P. \& Banga, A. (2014): Exploring Hungarian and Dutch gestural demonstratives. In: Veselovská, L. \& Janebová, M. (eds.): Complex Visibles Out There. Proceedings of the Olomouc Linguistics Colloquium 2014: Language Use and Linguistic Structure. Olomouc: Palacký University, 607-625.

Tóth, E. (2018): A production study on the choice of Hungarian demonstratives. Argumentum $14,110-123$.

Wilkins, D. (1999): Eliciting contrastive use of demonstratives for objects within close personal space (all objects well within arm's reach). In: Wilkins. D. (ed.): Manual for the 1999 Field Season. Nijmegen: Max Planck Institute for Psycholinguistics, 25-28.

Wilkins, D. (2018): The Demonstrative Questionnaire: "THIS" and "THAT" in Comparative Perspective. In: Levinson, S. C., Cutfield, S., Dunn, M. J., Enfield, N. \& Meira, S. (eds.): Demonstratives in Cross-Linguistic Perspective. Cambridge: Cambridge University Press, 43-71. https://doi.org/10.1017/9781108333818.003

Dr. Enikő Tóth

University of Debrecen

Institute of English and American Studies

H-4002 Debrecen

Pf. 400

toth.eniko@arts.unideb.hu 